\title{
Polyamine Biosynthesis in Human Fetal Liver and Brain
}

\author{
John A. Sturman ${ }^{[27]}$ and Gerald E. Gaull \\ Department of Pediatric Research, Institute for Basic Research in Mental Retardation, Staten Island, and Department of Pediatrics, \\ Division of Medical Genetics and Clinical Genetics Center, Mount Sinai School of Medicine of the City University of New York, \\ New York, New York, USA
}

\begin{abstract}
Extract
$S$-Adenosylmethionine decarboxylase specific activity in fetal $(9.0-25.0 \mathrm{~cm}$ crownrump length) human liver was 20 -fold greater than in mature human liver, both in the absence of putrescine $(63.1 \pm 7.2$ versus $3.5 \pm 0.8 \mathrm{pmol} \mathrm{CO} 2 / \mathrm{mg}$ protein $/ 30 \mathrm{~min})$ or in the presence of putrescine $\left(116.9 \pm 8.2\right.$ versus $6.2 \pm 1.0 \mathrm{pmol} \mathrm{CO} \mathrm{CO}_{2} / \mathrm{mg}$ protein $/ 30$ min). Extracts of fetal human brain did not have a significantly greater specific activity of $S$-adenosylmethionine decarboxylase than extracts of mature human brain when assayed in the absence of putrescine and had less when assayed in the presence of putrescine $(84.7 \pm 14.9$ versus $175.5 \pm 30.6 \mathrm{pmol} \mathrm{CO} 2 / \mathrm{mg}$ protein $/ 30 \mathrm{~min})$. Ornithine decarboxylase specific activity was greater in fetal liver than in mature liver $(8.8 \pm 1.6$ versus $1.1 \pm 0.3 \mathrm{pmol} \mathrm{CO} 2 / \mathrm{mg}$ protein $/ 30 \mathrm{~min}$ ) and 20 -fold greater in fetal brain than in mature brain $(71.2 \pm 12.1$ versus $3.1 \pm 1.4 \mathrm{pmol} \mathrm{CO} / \mathrm{mg}$ protein $/ 30 \mathrm{~min})$.

The concentration of putrescine was threefold greater in fetal human liver than in mature human liver $(21.6 \pm 2.7$ versus $6.5 \pm 0.5 \mu \mathrm{mol} / 100 \mathrm{~g})$ and eightfold greater in fetal human brain than in mature human brain $(42.9 \pm 2.3$ versus $5.5 \pm 0.6 \mu \mathrm{mol} / 100$ $\mathrm{g})$. The concentration of spermidine was fourfold greater in fetal human liver than in mature human liver $(81.2 \pm 1.6$ versus $21.4 \pm 1.2 \mu \mathrm{mol} / 100 \mathrm{~g})$, but its concentration in fetal human brain was not different from that in mature human brain. Spermine concentration was greater in fetal human liver than in mature human liver $(107.3 \pm$ 2.4 versus $70.7 \pm 6.8 \mu \mathrm{mol} / 100 \mathrm{~g}$ ) and greater in fetal human brain than in mature human brain $(30.7 \pm 1.8$ versus $22.1 \pm 0.9 \mu \mathrm{mol} / 100 \mathrm{~g})$.
\end{abstract}

\section{Speculation}

The pathway of methionine metabolism in human fetal liver and brain is adapted to conserve thie sulfur of homocysteine by delayed development of the trans-sulfuration of homocysteine to cysteine. This adaptation may implement RNA synthesis, as well as protein synthesis and DNA synthesis.

\section{Introduction}

Our previous studies $[3,4,20]$ on the trans-sulfuration pathway in human fetal liver and brain led to the conclusion that, in the 2nd trimester at least, the pathway was adapted for conservation of homocysteine. We found that in human fetal liver and brain cystathionase was virtually absent at this time, that betaine-homocysteine methyltransferase activity was decreased, and that N5-methyltetrahydrofolate-homocysteine methyltransferase activity was increased. We speculated that this 


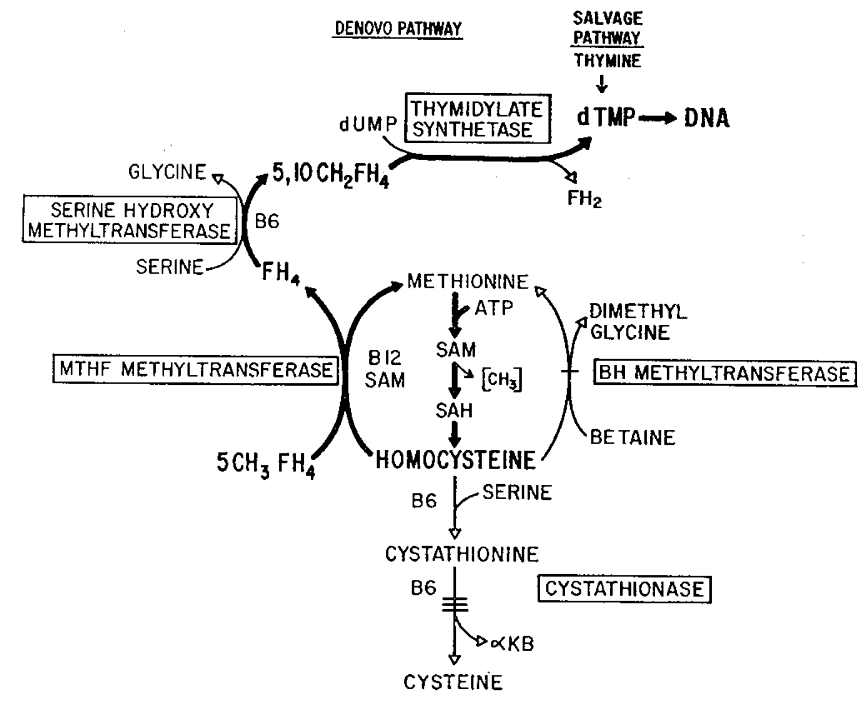

Fig. 1. Schematic representation of the interrelations between the methionine-homocysteine cycle, folate metabolism, and the synthesis of DNA and RNA. MTHF: $\mathrm{N}^{5}$-methyltetrahydrofolate; $S A M: S$-adenosylmethionine; $S A H: S$-adenosylhomocysteine; $B H$ : betaine-homocysteine; $\alpha K B: \alpha$-ketobutyrate; $5 \mathrm{CH}_{3} \mathrm{FH}_{4}: N^{5}, 10$. methyltctrahydrofolate; $5,10 \mathrm{CH}_{2} \mathrm{FH}_{4}: N^{5,}{ }^{10}$-methylenetetrahydrofolate.

represented an adaptation for channeling the $\beta$ carbon of serine into thymidylate, which is uniquely required for DNA synthesis, rather than channeling all of the carbons of serine to cysteine, and for the conservation of methionine by remethylation of homocysteine (see Fig. 1). This also ensures an adequate supply of $S$-adenosylmethionine, which is needed for many methylation reactions. Since trans-sulfuration is effectively shut off, the only losses from this methionine-homocysteine cycle are from incorporation of methionine into protein, which has been demonstrated to be actively occurring at this time of gestation [3], and by the decarboxylation of $S$-adenosylmethionine for synthesis of polyamines, particularly spermidine [11] (see Fig. 2). Methionine is maintained at a higher concentration in the fetal circulation than in the maternal circulation [2], as are most amino acids (with the notable exception of cyst(e)ine) and $\mathrm{N}^{5}$-methyltetrahydrofolate [9], and active accumulation presumably represents the mechanism for maintenance of the concentrations of these components of this cycle.

During the last decade a close association between the concentration of putrescine and of the polyamines, spermidine and spermine, and the growth process has been established [6]. These compounds are found in the highest concentrations in those tissues which actively synthesize RNA and protein. The enzymes, or- nithine decarboxylase and $S$-adenosylmethionine decarboxylase, which are critically involved in forming these amines from the precursor amino acids, ornithine and methionine, respectively, are unusual in that they have half-lives of the order of minutes [5, 19]. This suggests that these enzymes have special importance in the control of development, because their activity can be so rapidly increased. Thus, after partial hepatectomy in the rat, the activities of these enzymes increase rapidly, reach a peak after a few hours, and then decline slowly. During normal development there are similar bursts of these activities: for a few days early in development in chick embryos, at a later developmental stage in embryos of Xenopus laevis, and for a few days in the middle of gestation in the fetal rat. These short-lived periods of greatly increased activity are apparently priming the tissue about to undergo proliferation or rapid growth [6]. Inasmuch as the appearance of these enzymatic activities during development varies somewhat from species to species, we have studied the activities of these enzymes in human fetal liver and brain (2nd

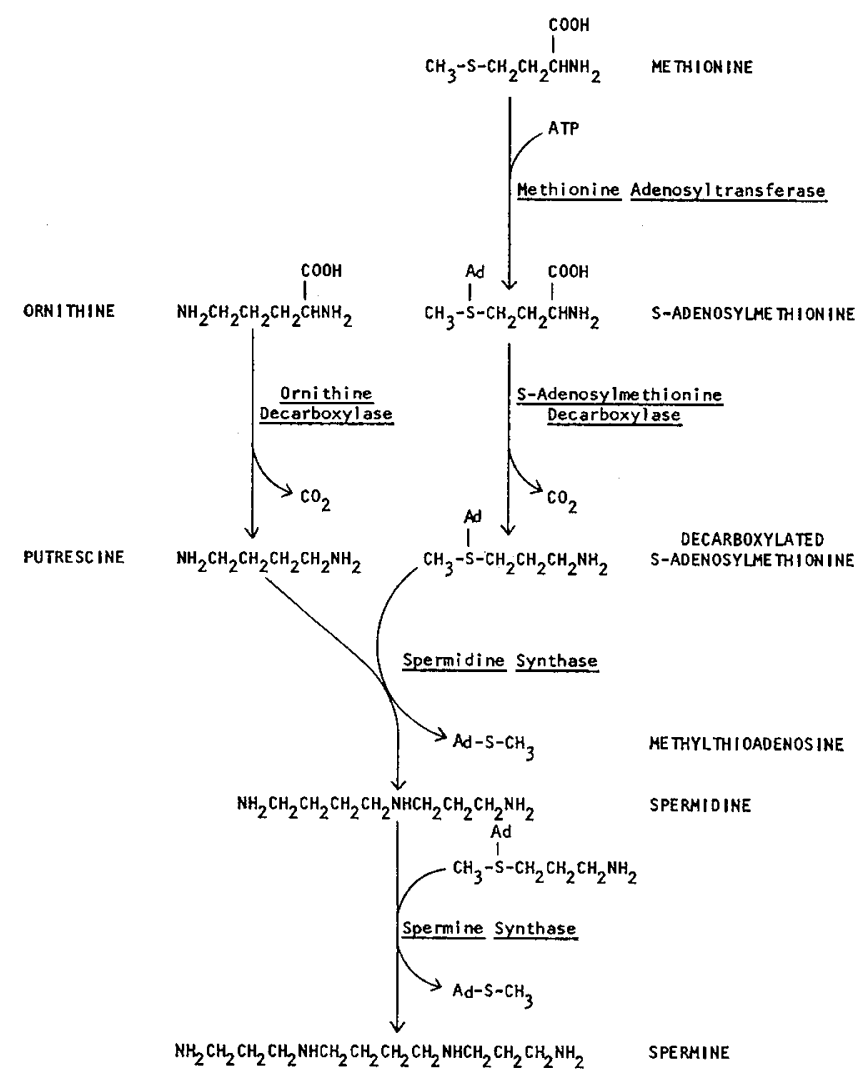

Fig. 2. Pathway for biosynthesis of putrescine and the polyamines, spermidine and spermine. $A d$ : adenosyl. 
trimester), together with concentration of the relevant amines in the same tissues.

\section{Materials and Methods}

Liver and brain of human fetuses (crown-rump length $9.0-25.0 \mathrm{~cm}$ ) were removed immediately after therapeutic abortion by hysterotomy, rapidly frozen in liquid nitrogen, and stored at $-70^{\circ}$. Apparently normal samples of liver and occipital lobe of adult humans were obtained at autopsy within $36 \mathrm{hr}$ of unnatural death and stored at $-70^{\circ}$. Studies with liver taken from rats immediately after death, $24 \mathrm{hr}$ and $48 \mathrm{hr}$ after death showed no difference in activity of $S$-adenosylmethionine decarboxylase or ornithine decarboxylase, and indicated that results obtained from the autopsy material are indeed valid. Furthermore, one sample of liver obtained only $1.5 \mathrm{hr}$ after death had enzymatic activity similar to liver samples obtained somewhat later after death.

For assay of enzymatic activities, the tissues were homogenized with 2 volumes of $0.03 \mathrm{M}$ potassium phosphate buffer, $\mathrm{pH} 6.9$, and centrifuged at $12,000 \times \mathrm{g}$ for $30 \mathrm{~min}$. The supernatant fluid was recentrifuged at $40,000 \times g$ for $60 \mathrm{~min}$ and either used immediately or stored at $-70^{\circ}$. Protein concentration was determined by the Lowry method [10].

The activities of $S$-adenosylmethionine decarboxylase and ornithine decarboxylase were determined by measuring the release of ${ }^{14} \mathrm{CO}_{2}$ from carboxyl-labeled substrate, essentially as described by Pegg and WilliamsAshman [12] and Russell and Snyder [16], respectively. The standard reaction mixture for assay of $S$-adenosylmethionine decarboxylase activity contained $10 \mu \mathrm{mol}$ sodium phosphate buffer, $\mathrm{pH} 7.2,0.25 \mu \mathrm{mol}$ putrescine (when present), $0.025 \mu \mathrm{mol}$ (approximately 250,000 $\mathrm{dpm})\left({ }^{14} \mathrm{C}\right)$ carboxyl $S$-adenosylmethionine [22], and tissue extract in a total volume of $0.1 \mathrm{ml}$. The exact concentration and radiopurity of the $S$-adenosylmethionine was determined using an amino acid analyzer coupled with a flow-cell scintillation counter. The radiopurity was greater than $90 \%$ for all $S$-adenosylmethionine samples used in this work. The reaction mixture used for assay of ornithine decarboxylase activity contained 10 $\mu \mathrm{mol}$ sodium phosphate buffer, $\mathrm{pH} 7.2,0.005 \mu \mathrm{mol}$ pyridoxal phosphate, $0.0225 \mu \mathrm{mol}$ (approximately $250,000 \mathrm{dpm})\left({ }^{14} \mathrm{C}\right)$ carboxyl ornithine [22], $0.5 \mu \mathrm{mol} \mathrm{di}-$ thiothreitol, and tissue extract in a total volume of 0.1 $\mathrm{ml}$. For both assays, the extracts were incubated at $37^{\circ}$ for $30 \mathrm{~min}$, and the reactions terminated by the injec- tion of $0.9 \mathrm{ml} 5 \mathrm{~N} \mathrm{H}_{2} \mathrm{SO}_{4} \cdot{ }^{14} \mathrm{CO}_{2}$ was collected by 0.25 $\mathrm{ml} 20 \% \mathrm{KOH}$ in a polypropylene well. The well was removed into a counting vial containing $1 \mathrm{ml}$ water and $10 \mathrm{ml}$ scintillation fluid $(33 \%$ Triton $\mathrm{X}-100,0.55 \%$ 2,5-diphenyloxazole, and 0.01\% 1,4-bis[2-(4-methyl-5phenyloxazolyl)]-benzene in toluene) and counted twice in a liquid scintillation spectrometer [23] for $10 \mathrm{~min}$. Each assay was carried out in duplicate and accompanied by a blank using heat-inactivated extract $\left(80^{\circ}\right.$ for $2 \mathrm{~min}$ ). The latter precaution is mandatory because of the ease with which both substrates can be decarboxylated nonenzymatically in the presence of pyridoxal phosphate $[1,18]$. The inclusion of dithiothreitol in the assay of ornithine decarboxylase was especially important for measuring activity in fetal brain extracts, which had only trace amounts of activity when it was left out. Some fetal brain tissue was homogenized in buffer containing $1 \%$ Triton X-100 but it still exhibited only trace amounts of activity in the absence of dithiothreitol. Some extracts of fetal brain were dialyzed against $0.03 \mathrm{M}$ potassium phosphate buffer, $\mathrm{pH}$ 6.9 , containing $0.05 \mathrm{~mm}$ pyridoxal phosphate, for $24 \mathrm{hr}$ at $4^{\circ}$ before assaying for ornithine decarboxylase activity, but still only trace amounts were detected in the absence of dithiothreitol. Therefore, it seems unlikely that an inhibitor, inactivated by dithiothretiol, is present. Evidence has been presented that, in the absence of thiol reagents, the enzyme from rat prostate exists in a polymeric form with greatly reduced enzymatic activity [7].

Extracts of liver and brain for determination of concentrations of amines were prepared by homogenizing with 3 volumes of $10 \%$ trichloroacetic acid and centrifuging at $10,000 \times g$ for $30 \mathrm{~min}$. Analysis of putrescine, spermidine, and spermine was carried out with an automatic amino acid analyzer [24] equipped with two 9-cm columns of PA-35 resin operated in tandem. All buffers referred to are $0.2 \mathrm{~N}$ sodium acetate, $\mathrm{pH} 5.55$, made up to high molarities with sodium chloride. The columns were regenerated with $2.4 \mathrm{~N}$ buffer and the samples eluted at $55^{\circ}$ with a gradient made up from 70 $\mathrm{ml} 3.5 \mathrm{~N}$ buffer in one chamber and $70 \mathrm{ml} 5.0 \mathrm{~N}$ buffer in a second chamber. With this system, putrescine, spermidine, and spermine were well separated and eluted in 26, 40, and $54 \mathrm{~min}$, respectively, which allowed many analyses to be performed in a working day. Preliminary analysis by a longer column method which gave much greater separations had shown that these three compounds were the only significant ninhydrin-positive substances eluted in this region. 


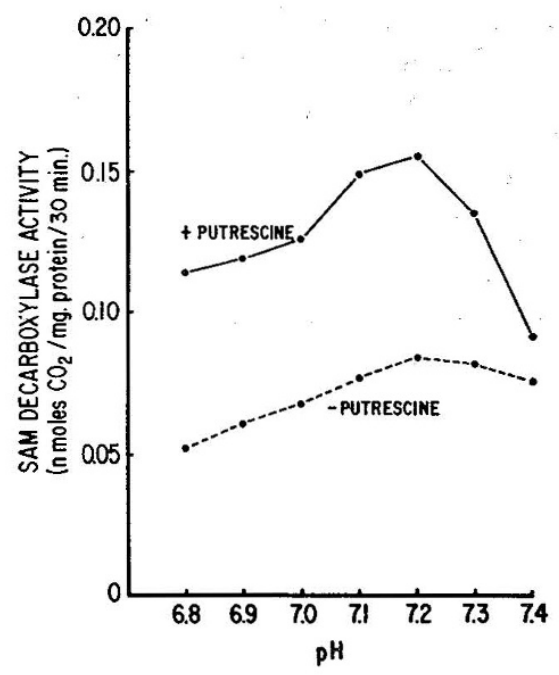

Fig. 3. Activity of $S$-adenosylmethionine $(S A M)$ decarboxylase of human fetal liver as a function of $\mathrm{pH}$.

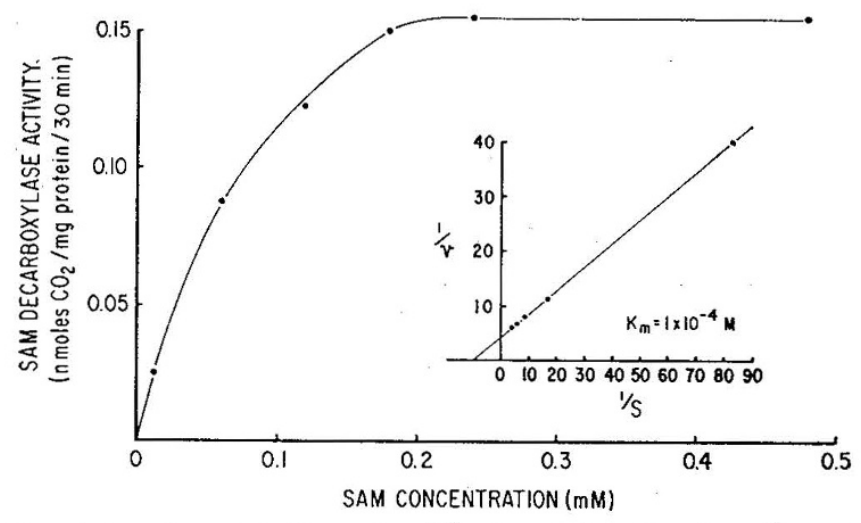

Fig. 4. Activity of $S$-adenosylmethionine $(S A M)$ decarboxylase of human fetal liver as a function of $S$-adenosylmethionine concentration. Inset: double reciprocal plot for estimation of $\mathrm{K}_{\mathrm{m}}$.

\section{Results}

Studies of the decarboxylation of $S$-adenosylmethionine by human fetal liver extracts showed that the production of $\mathrm{CO}_{2}$ was proportional to the amount of protein added up to at least $2.33 \mathrm{mg}$, was greatest at $\mathrm{pH} 7.2$ (Fig. 3), and proportional to the time of incubation up to $30 \mathrm{~min}$. Beyond $40 \mathrm{~min}$ the rate of production decreased rapidly. The rate of production of $\mathrm{CO}_{2}$ was maximal at the concentration of $S$-adenosylmethionine used (Fig. 4), and remained constant up to $0.5 \mathrm{~mm}$. The apparent $\mathrm{K}_{\mathrm{m}}$ of the human fetal liver enzyme was $1 \times$ $10^{-4} \mathrm{M}$ (inset, Fig. 4) which is the same order of magnitude as values reported for the rat and human prostate enzyme [12, 21] and for the rat brain enzyme [17]. Storage of rat liver and rat liver extract at $-70^{\circ}$ caused no change in activity up to 3 months. The specific activity of $S$-adenosylmethionine decarboxylase in both fetal liver and fetal brain showed no correlation with crown-rump length, and, therefore, the results are presented as the mean $\pm \mathrm{sE}$.

Studies of the decarboxylation of ornithine by human fetal brain extracts showed that the production of $\mathrm{CO}_{2}$ was proportional to the amount of protein added up to at least $1.18 \mathrm{mg}$, was greatest at pH 7.2 (Fig. 5), and proportional to the time of incubation up to 30 min. The rate of production of $\mathrm{CO}_{2}$ was approximately two-thirds maximal at the concentration of ornithine used (Fig. 6), the maximum rate not being attained until the substrate concentration was greater than 1 mM. Some experiments were performed using $2 \mathrm{~mm}$ ornithine concentration, and, although the sensitivity of the assay is low under these conditions, the same results were obtained. The apparent $\mathrm{K}_{\mathrm{m}}$ of the human fetal brain enzyme was $1.3 \times 10^{-4} \mathrm{M}$ (inset, Fig. 6), which is similar to values for the rat prostate enzyme and regenerating rat liver enzyme [7, 13]. The specific activity of ornithine decarboxylase in both fetal liver and fetal brain showed no correlation with crown-rump length, and therefore the results are presented as the mean $\pm \mathrm{sE}$.

Extracts of human fetal liver had a 20 -fold greater specific activity of $S$-adenosylmethionine decarboxylase and an 8-fold greater specific activity of ornithine decarboxylase than extracts of mature human liver (Tables $I$ and II). The concentration of their products,

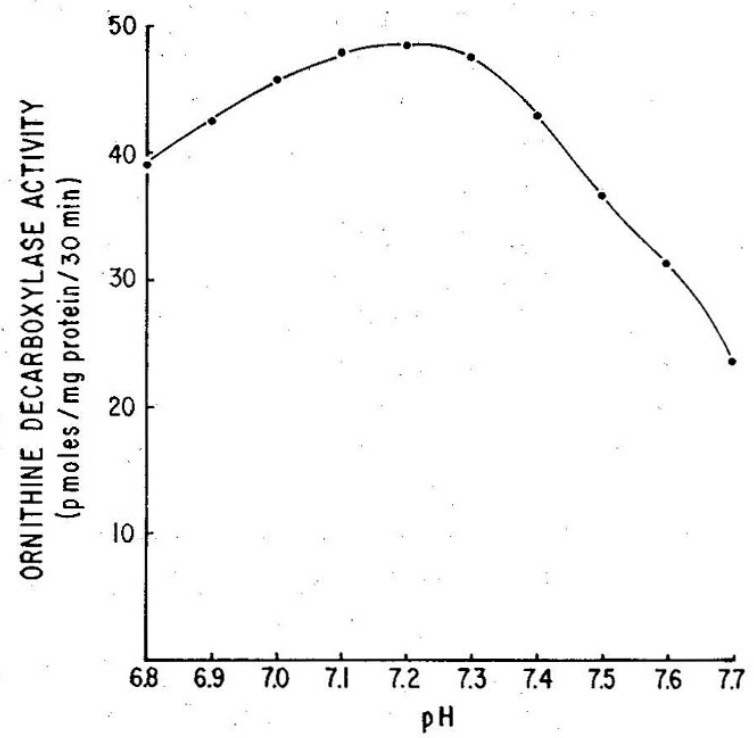

Fig. 5. Activity of ornithine decarboxylase of human fetal brain as a function of $\mathrm{pH}$. 
spermidine and putrescine, respectively, were fourfold greater and threefold greater in fetal liver than in mature liver (Table III). The concentration of spermine was also significantly greater in fetal liver than in mature liver (Table III).

Extracts of whole fetal brain had twofold less specific activity of $S$-adenosylmethionine decarboxylase than extracts of mature occipital lobe, when assayed in the presence of exogenous putrescine, but were not significantly different when assayed in its absence (Table I). The added putrescine increased the activity of $S$ adenosylmethionine decarboxylase in extracts of mature brain $400 \%$, although it increased the activity in extracts of fetal brain by only $25 \%$. Extracts of fetal brain had a 20-fold greater specific activity of ornithine decarboxylase than extracts of mature occipital lobe

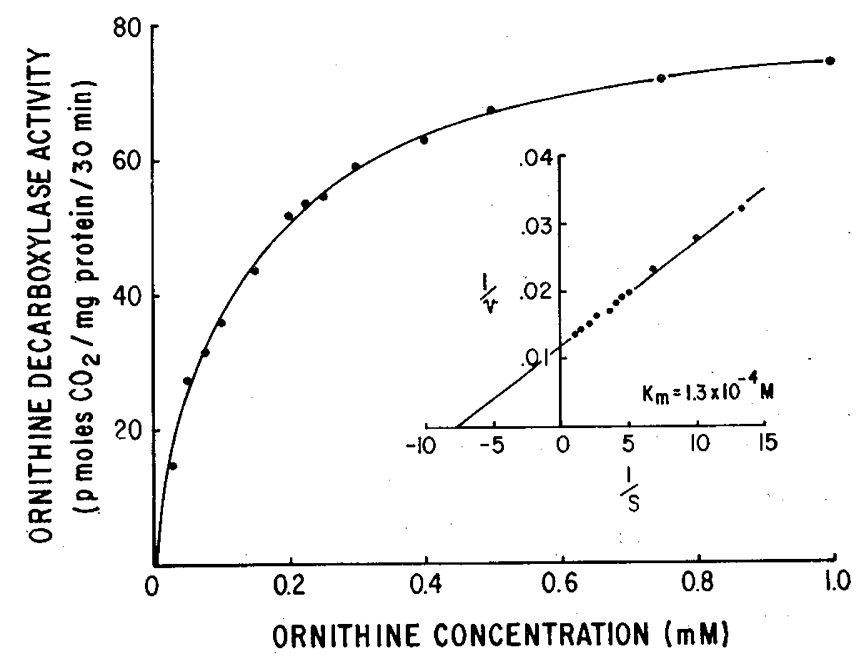

Fig. 6. Activity of ornithine decarboxylase of human fetal brain as a function of ornithine concentration. Inset: double reciprocal plot for estimation of $\mathrm{K}_{\mathrm{m}}$.

Table I. S-Adenosylmethionine decarboxylase activity in human liver and brain ${ }^{1}$

\begin{tabular}{lcc}
\hline & \multicolumn{2}{c}{ Activity, pmol $\mathrm{CO}_{2} / \mathrm{mg}$ protein $/ 30 \mathrm{~min}$} \\
\cline { 2 - 3 } & - Putrescine & +Putrescine \\
\hline Liver & & \\
$\quad$ Mature (5) & $3.5 \pm 0.8$ & $6.2 \pm 1.0$ \\
$\quad$ Fetal (25) & $63.1 \pm 7.2^{2}$ & $116.9 \pm 8.2^{2}$ \\
Brain & & \\
$\quad$ Mature (6) & $38.0 \pm 16.2$ & $175.5 \pm 30.6$ \\
$\quad$ Fetal (12) & $65.7 \pm 10.7^{3}$ & $84.7 \pm 14.9^{2}$ \\
\hline
\end{tabular}

1 Number of organs is shown in parentheses.

2 Significantly different from the appropriate mature value as determined by the Student $t$ test $(P<0.005)$.

${ }^{3}$ Not significantly different from the mature value as determined by the Student $t$ test.
Table II. Ornithine decarboxylase activity in human liver and brain $^{1}$

Activity, $\mathrm{pmol} \mathrm{CO}_{2} / \mathrm{mg}$ protein $/ 30 \mathrm{~min}$ :

$\begin{array}{lc}\text { Liver } & \\ \quad \text { Mature (5) } & 1.1 \pm 0.3 \\ \quad \text { Fetal (24) } & 8.8 \pm 1.6^{2} \\ \text { Brain } & \\ \quad \text { Mature (6) } & 3.1 \pm 1.4 \\ \quad \text { Fetal (18) } & 71.2 \pm 12.1^{2}\end{array}$

${ }^{1}$ Number of organs is shown in parentheses.

2 Significantly different from the appropriate mature value as determined by the Student $t$ test $(P<0.005)$.

Table III. Concentration of putrescine and of polyamines in human liver and brain ${ }^{1}$

\begin{tabular}{lccc}
\hline & \multicolumn{3}{c}{ Concentration, $\mu \mathrm{mol} / 100 \mathrm{~g}$ wet wt } \\
\cline { 2 - 4 } & Putrescine & Spermidine & Spermine \\
\hline Liver & & & \\
$\quad$ Mature (5) & $6.5 \pm 0.5$ & $21.4 \pm 1.2$ & $70.7 \pm 6.8$ \\
$\quad$ Fetal (12) & $21.6 \pm 2.7^{2}$ & $81.2 \pm 1.6^{2}$ & $107.3 \pm 2.4^{2}$ \\
Brain & & & \\
$\quad$ Mature (5) & $5.5 \pm 0.6$ & $40.7 \pm 3.0$ & $22.1 \pm 0.9$ \\
Fetal (12) & $42.9 \pm 2.3^{2}$ & $35.8 \pm 1.4^{3}$ & $30.7 \pm 1.8^{2}$ \\
\hline
\end{tabular}

${ }^{1}$ Number of organs is shown in parentheses.

${ }^{2}$ Significantly different from appropriate mature value as determined by the Student $t$ test $(P<0.01)$.

${ }^{3}$ Not significantly different from the mature value as determined by the Student $t$ test.

(Table II). In whole fetal brain, the concentration of the product of ornithine decarboxylase, putrescine, was eightfold greater than that in mature occipital lobe (Table III). The concentration of spermidine in fetal brain was similar to that in mature brain, but the concentration of spermine in fetal brain was greater than that in mature brain.

\section{Discussion}

The finding of a greater specific activity of $S$-adenosylmethionine decarboxylase and of ornithine decarboxylase in extracts of fetal liver than in mature liver (Tables I and II) and of greater concentrations of putrescine and the polyamines, spermidine and spermine, in fetal liver than in mature liver (Table III) fits with other evidence that, at this stage of development, human fetal liver is rapidly synthesizing RNA and protein $[3,8]$. The activity of ornithine decarboxylase in human fetal liver, at this stage of development, although greater than in mature liver, is still less than in fetal brain. However, the peaks of activities of brain 
and liver ornithine decarboxylase do not coincide in the rat embryo [15], and it is possible that greater activities of ornithine decarboxylase in human fetal liver occur outside the gestational age of the human fetuses we studied.

The findings in human fetal brain during the 2nd trimester are not quite as clear as those in fetal liver during this period. The specific activity of ornithine decarboxylase is far greater in fetal brain than it is in mature occipital lobe (Table $\mathrm{M}$ ). The functional significance of this finding is underscored by the fact that putrescine, the produce of ornithine decarboxylase, is also present in far greater concentrations in fetal brain. However, neither the specific activity of $S$-adenosylmethionine decarboxylase (Table I) nor the concentration of spermidine (Table III) are greater in fetal brain, although the concentration of spermine is somewhat greater in fetal brain. Indeed, the specific activity of $S$-adenosylmethionine decarboxylase, when stimulated by excess putrescine, is actually significantly less in fetal brain. In human fetal liver, the concentrations of RNA and protein, as well as DNA, reach a peak during the middle of the 2nd trimester, whereas, in fetal brain during this period, the concentration of RNA and protein are constant, and that of DNA is decreasing [8]. The concentration of spermidine has been closely correlated with the synthesis of RNA and protein [6]. Thus, our finding of a greater concentration of spermidine in 2nd trimester fetal liver than in mature liver, but the same concentration of spermidine in 2nd trimester fetal brain as in mature occipital lobe, and our similar findings with regard to $S$-adenosylmethionine decarboxylase, are thereby understandable.

Recently, it has been directly demonstrated that putrescine is involved in the control of RNA synthesis in rat brain, inasmuch as the intracisternal injection of putrescine before the intracisternal injection of $\left({ }^{14} \mathrm{C}\right)$ uridine resulted in greater incorporation of radioactivity into RNA in brain [14]. This effect might be direct, but is probably mediated via the synthesis of spermidine, and the mechanism of control of synthesis of spermidine apparently is intricate. Synthesis of spermidine may be increased either by increasing the amount of $S$-adenosylmethionine decarboxylase or by increasing the activity of the existing enzyme with putrescine. Moreover, the supply of putrescine is regulated by the activity of ornithine decarboxylase. Exogenous putrescine increased the activity of $S$-adenosylmethionine decarboxylase in extracts of fetal brain by only $25 \%$, whereas it increased the activity measurable in mature brain extracts by more than $400 \%$. Presumably, the smaller percentage of increase of the fetal brain extracts with exogenous putrescine is because of the greater endogenous concentration of putrescine in the fetal brain (Table III). However, the activity measured without added putrescine is probably more representative of the in vivo activity, and this is not significantly greater in extracts of fetal brain than it is in extracts of mature brain.

The fact that the maximum potential for $S$-adenosylmethionine decarboxylase activity, i.e., with added putrescine, is greater in mature brain may have considerable functional significance. With or without putrescine, there is a far greater specific activity of $S$-adenosylmethionine decarboxylase in mature brain than there is in mature liver. The greater activity of this enzyme in brain is in agreement with the results of Schmidt and Cantoni [17], who found considerable activity of this enzyme in mature rat brain and suggested that synthesis of spermidine may be important in the maintenance of the brain as a functioning organ. They pointed out that the development of $S$-adenosylmethionine decarboxylase in whole rat brain is similar to the development of the enzymes involved in oxidative metabolism and to the enzymes involved in the synthesis of putative neurotransmitter substances, to the development of synaptogenesis, and to the development of electric activity. Thus, in addition to being involved in the synthesis of macromolecules during growth, spermidine may be involved in the later synthesis of the specialized neural membranes.

In a general way, the present results establish that polyamine synthesis in the liver and brain of the $2 n d$ trimester human fetus is great. They thereby extend and give further evidence for the hypothesis that transsulfuration in human fetal liver and in human fetal brain is incomplete in order to conserve homocysteine $[3,4,20]$ (Fig. 1). The inability to convert homocysteine to cysteine and the increased ability to remethylate homocysteine back to methionine would help ensure a sufficient supply of methionine and $S$-adenosylmethionine for biosynthetic needs. In this case, the increased biosynthetic needs are related to the generation of polyamines and thereby, the synthesis of RNA, as well as to the synthesis of DNA $[3,4,20]$.

\section{Summary}

Specific activity of $S$-adenosylmethionine decarboxylase was higher in liver of the human fetus (2nd trimester) than in liver from the mature human. There was no 
difference in specific activity between fetal and mature brain. Specific activity of ornithine decarboxylase was higher in both liver and brain from the human fetus than from the same organs from the mature human. Putrescine, spermidine, and spermine were present in higher concentrations in fetal liver than mature liver, whereas only putrescine and spermine concentrations were greater in fetal brain than mature brain.

\section{References and Notes}

1. Coppoc, G. L., Kallio, P., and Williams-Ashman, H. G.: Characteristics of $S$-adenosyl-L-methionine decarboxylase from various organisms. Int. J. Biochem., 2: 673 (1971).

2. GaUll, G. E., Rärhä, N. C. R., SaArikoski, S., and Sturman, J. A.: Transfer of cyst(e)ine and methionine across the human placenta. Pediat. Res., 7: 908 (1973).

3. Gaull, G. E., Sturman, J. A., and Rärhä, N. C. R.: Development of mammalian sulfur metabolism: Absence of cystathionase in human fetal tissues. Pediat. Res., 6: 538 (1972).

4. Gaull, G. E., von Berg, W., Rärhä, N. C. R., and Sturman, J. A.: Development of methyltransferase activities of human fetal tissues. Pediat. Res., 7: 527 (1973).

5. Hannonen, P., Raina, A., And Jänne, J.: Polyamine synthesis in the regenerating rat liver: Stimulation of $S$-adenosylmethionine decarboxylase, and spermidine and spermine synthases after partial hepatectomy. Biochim. Biophys. Acta, 273: 84 (1972).

6. Herbst, E. J., ANd Bachrach, U. (Eds.): Metabolism and biological function of polyamines. Ann. N. Y. Acad. Sci., 171: $691(1970)$.

7. JäNNE, J., AND Williams-Ashman, H. G.: On the purification of L-ornithine decarboxylase from rat prostate and effects of thiol compounds on the enzyme. J. Biol. Chem., 246: 1725 (1971).

8. Kapeller-Adler, R., and Hammad, W. A.: A biochemical study of nucleic acids and protein synthesis in the human fetus and its correlation with relevant embryological data. J. Obstet. Gynecol. Brit. Commun., 79: 924 (1972).

9. LANDon, M. J., AND OXLeY, A.: Relation between maternal and infant blood folate activities. Arch. Dis. Childhood, 46: 810 (1971).

10. Lowry, O. H., Rosebrough, N. J., Farr, A. L., AND RANDall, R. J.: Protein measurement with the Folin phenol reagent. J. Biol. Chem., 193: 265 (1951).

11. PegG, A. E., And Williams-Ashman, H. G.: Stimulation of the decarboxylation of $S$-adenosylmethionine by putrescine in mammalian tissues. Biochem. Biophys. Res. Commun., 30: 76 (1968).
12. PEgG, A. E., and Williams-Ashman, H. G.: On the role of $S$ adenosyl-L-methionine in the biosynthesis of spermidine by rat prostate. J. Biol. Chem., 244: 682 (1969).

13. RAINA, A., AND JÄNNE, J.: Biosynthesis of putrescine: Characterization of ornithine decarboxylase from regenerating rat liver. Acta Chem. Scand., 22: 2375 (1968).

14. Reynolds, A. F., And Russell, D. H.: Stimulation of ${ }^{14} \mathrm{C}$ uridine incorporation into RNA by intracisternal injection of putrescine (Abstract). Fed. Proc., 32: 429 (1973).

15. Russell, D. H.: Discussion: Putrescine and spermidine biosynthesis in growth and development. Ann. N. Y. Acad. Sci., 171: 772 (1970).

16. RuSSEll, D. H., AND SNYDER, S. H.: Amine synthesis in rapidly growing tissues: Ornithine decarboxylase activity in regenerating rat liver, chick embryo, and various tumors. Proc. Nat. Acad. Sci., 60: 1420 (1968).

17. Schimid, G. L., and Cantoni, G. L.: Adenosylmethionine decarboxylase in developing rat brain. J. Neurochem., 20: 1373 (1973).

18. SNell, E. E., AND Dimari, S. I.: Schiff base intermediates in enzyme catalysis. In: P. Boyer: The Enzymes, Ed. 3, Vol. 2, p. 335 (Academic Press, New York, 1970).

19. Snyder, S. H., Kreuz, D. S., Medina, V. J., ANd Russell, D. H.: Polyamine synthesis and turnover in rapidly growing tissues. Ann. N. Y. Acad. Sci., 171: 749 (1970).

20. Sturman, J. A., Gaull, G. E., And Rärï̈, N. C. R.: Absence of cystathionase in human fetal liver: Is cystine essential? Science, 169: 74 (1970).

21. Zappia, V., Carteni-Farina, M., and Pietra, G. D.: S-Adenosylmethionine decarboxylase from human prostate: Activation by putrescine. Biochem. J. 129: 703 (1972).

22. Obtained from Amersham-Searle Corporation, Arlington Heights, 111.

23. Packard Tri-Carb model 3375, Packard Instruments Corporation, Downers Grove, Ill.

24. Beckman model 120C, Beckman Instruments, Spinco Division, Palo Alto, Calif.

25. We thank Mrs. Judith Fagan and Mr. Gerald Poje for expert assistance during much of this work. Many of the samples of fetal liver and brain were the same as those used in a previous study [4]. The help of Dr. Niels Räihä in obtaining these samples is gratefully acknowledged.

26. This research was supported by the New York State Department of Mental Hygiene and National Institutes of Health Clinical Genetics Center Grant no. GM 19443.

27. Requests for reprints should be addressed to: J. A. Sturman, Ph.D., Department of Pediatric Research, New York State Institute for Basic Research in Mental Retardation, 1050 Forest Hill Rd., Staten Island, N. Y. 10314 (USA).

28. Accepted for publication November 15, 1973. 